\title{
Stride kinematic changes in laminitic horses treated with three different types of hoof orthopedic devices
}

\section{Alterações cinemáticas da locomoçāo em cavalos com laminite tratados com três diferentes tipos de órteses para o casco}

\author{
Cahuê Francisco Rosa Paz'; Túlio Luiz Banja Fernandes²; Leopoldo Augusto \\ Paolucci $^{3}$; Alvaro de Paula Lage de Oliveira ${ }^{1}$; Thairê Pereira Maróstica ${ }^{4}$; Marcos \\ Paulo Antunes de Lima ${ }^{1}$; André Gustavo Pereira de Andrade ${ }^{5}$; Luiz Alberto do \\ Lago $^{6}$; Rafael Resende Faleiros ${ }^{6 *}$
}

\begin{abstract}
Considering the hypothesis that laminitic horses display changes in the kinematics of their forelimbs and clog type orthopedic devices can be beneficial in such cases, the objectives of this study were to compare the stride pattern of healthy horses versus that of horses with chronic laminitis and to assess the kinematic effects of three types of clog shoes on the stride of laminitic horses. Six healthy and six laminitic mares were subjected to a kinematic evaluation at a walk. The horses with laminitis were evaluated before and after the use of three different models of clog type orthopedic shoes on the hooves of both their forelimbs. The treatment types that were administered were the application of no shoes, wooden shoes, leather and ethylene-vinyl acetate (EVA) shoes, and wooden and EVA shoes. The horses with laminitis have a stride length that is reduced by $11 \%(\mathrm{P}=0.03)$, and in the swing phase, by $18 \%(\mathrm{P}$ $=0.004)$, and the relative stance phase of each limb is prolonged by $6 \%(\mathrm{P}=0.02)$ when compared with the healthy group. However, values associated with the stride duration, stance phase duration, breakover duration, speed, and frequency were not significantly different among the laminitic groups. Further, no statistical differences were found in the comparison of the outcomes among the treatments administered to the horses with laminitis, except in their stride length, which was longer in the horses shod with wooden clogs when compared with in the unshod laminitic horses $(P=0.04)$. It was concluded that horses with stable chronic laminitis display changes in the kinematics of their forelimbs while walking. Immediate and remarkable beneficial effects were not observed with the use of all the types of orthoses; however, the wooden clog resulted in a significant improvement in the length of the stride. Further studies are needed to verify the prolonged effects of clog shoe-type ortheses in the different phases of equine laminitis.
\end{abstract}

Key words: Equine. Kinematics analysis. Orthosis.

\footnotetext{
${ }^{1}$ Discentes, Programa de Pós-Graduação em Ciência Animal, Escola de Veterinária, Universidade Federal de Minas Gerais, UFMG, Belo Horizonte, MG, Brasil. E-mail: cahuepaz@gmail.com; oliveira.medvet@hotmail.com; limampa@hotmail.com

2 Prof., Instituto de Educação Física e Esportes, Universidade Federal do Ceará, UFC, Fortaleza, CE, Brasil. E-mail: tuliobanja@ gmail.com

3 Discente, Programa de Pós-Graduação em Engenharia de Estruturas, Escola de Engenharia, UFMG, Belo Horizonte, MG, Brasil. E-mail: leobia2009@yahoo.com.br

4 Discente, Escola de Veterinária, UFMG, Belo Horizonte, MG, Brasil. E-mail: thairepereira@gmail.com

5 Prof., Departamento de Esportes, Escola de Educação Física, Fisioterapia e Terapia Ocupacional, UFMG, Belo Horizonte, MG, Brasil. E-mail: andreguto@yahoo.com.br

6 Profs., Departamento de Clínica e Cirurgia, Escola de Veterinária, UFMG, Belo Horizonte, MG, Brasil, Brasil. E-mail: lago@ vet.ufmg.br; faleirosufmg@gmail.com

* Author for correspondence
} 


\section{Resumo}

Com a hipótese de que a laminite promove alterações cinemáticas nos membros torácicos e que a utilização de órteses no casco pode beneficiar a biomecânica da locomoção, o objetivo foi comparar o padrāo temporal da passada de equinos saudáveis e com laminite crônica e mensurar os efeitos de três diferentes tipos de órteses utilizando análise cinemática. Foram utilizados equinos adultos da raça Mangalarga Marchador, seis éguas saudáveis e seis com laminite crônica. Os animais com laminite foram avaliados antes e após o uso de três modelos de órteses do tipo "clog shoe". Os tratamentos foram: controle (sem órtese), órtese de madeira, órtese de couro e etileno acetato de vinila (EVA) e órtese de madeira com EVA. Os cavalos com laminite reduziram o comprimento da passada em $11 \%$ $(\mathrm{P}=0,03)$, reduziram a fase de elevaçāo em $18 \%(\mathrm{P}=0,004)$ e prolongaram a fase relativa de apoio do membro em $6 \%(\mathrm{P}=0,02)$ em relação aos cavalos sadios. Não foram encontradas diferenças estatísticas na comparação entre os cavalos com laminite, com exceçāo do comprimento da passada, que mostrouse maior nos cavalos com a órtese de madeira em comparação aos cavalos com laminite sem órtese $(\mathrm{P}=0,04)$. Conclui-se que equinos com laminite crônica estável apresentam alterações na cinemática de membros torácicos ao passo. Não foram observados efeitos benéficos imediatos com o emprego de todos os tipos de órteses, contudo a de madeira proporcionou melhora significativa no comprimento da passada. Novos estudos se fazem necessários para verificar em médio e longo prazos os efeitos das órteses na laminite de equinos em diferentes fases.

Palavras-chave: Análise cinemática. Equinos. Órtese.

Horseshoes have always been used with the original purpose of protecting the hoof from excessive wear. However, over the years, many types of horseshoes and trimming techniques have been developed to maintain or improve the functionality of locomotion and for therapeutic purposes (ELIASHAR, 2012). All the diseases affecting the hooves of horses require therapeutic care that involves specific trimming and shoeing. Laminitis is not an exception; however, the chronically laminitic horse is often a very difficult case to manage. This condition occurs due to the displacement of the coffin bone within the hoof capsule that leads to chronic pain and ongoing damage to the soft tissues of the foot. In spite of these difficulties, veterinarians and farriers have worked together to collectively obtain satisfactory results in the treatment of laminitis cases, both acute and chronic, treating each horse individually and respecting their particularities.

Many aspects have contributed to the positive results acheived in laminitis cases, including a better understanding of the mechanisms related to the pathophysiology. This knowledge resulted in more effective pharmaceutical therapies and preventive care against systemic diseases that put a horse at the risk of developing laminitis and more effective approaches in order to support the affected digit. The pharmaceutical therapies are intended to prevent or minimize distal phalangeal displacement and to decrease pain (BELKNAP, 2017). On the other hand, therapeutic shoeing, based on biomechanical principles, is used to improve the form and function of the hoof (ELIASHAR, 2007). The practice of therapeutic shoeing in the case of equine chronic laminitis has the following objectives related to hoof biomechanics: to support the hoof using the frog and sole, to move the center of the pressure palmar/plantar, to change the breakover in a palmar/ plantar direction in order to facilitate the take-off movement of the hoof, and to decrease the tension in the deep digital flexor tendon (DDFT) using heel elevation. These practices reduce the weightbearing of the dorsal hoof wall and thereby reduce the stress on the lamellae while decreasing the moment arm around the distal interphalangeal joint (O'GRADY; STEWARD, 2009). Among the types of horseshoes that are used for horses with chronic laminitis, wooden shoes (also called clog shoes) have recently received a great deal of attention 
(STEWARD, 2003; O'GRADY; PARKS，2008; O’GRADY, 2013).

This type of orthosis, made from plywood and fixed to the hoof with screws and/or casting tape, provides many of the biomechanical changes to the foot that have been mentioned above. O'Grady (2013) has stated that the use of wooden shoes promotes hoof wall and sole growth to realign the distal phalanx within the hoof capsule. This same author also describes other advantages: simplicity of construction, mechanics such as breakover and heel elevation that can be fabricated into the shoe, and the beveled perimeter of the shoe that concentrates the load under the distal phalanx (and away from the hoof wall/lamellae). The provision of the solid base of the shoe also allows for the maximum recruitment of the surface area in the palmar/plantar section of the foot to accept load when combined with an appropriate amount of impression material that places even pressure and load across the palmar/ plantar section of the foot.

Currently, the clog shoe is used as a temporary horseshoe on horses with chronic laminitis, and there is no doubt about the benefits of its use. However, according to Parks (2017), details regarding the satisfactory results generated from using these shoes have been obtained from testimonials. There are no controlled studies that have documented anecdotal reports on the satisfactory results generated using clog shoes, possibly due to the lack of uniformity in the presentation of horses with laminitis and the difficulty in persuading clinicians to use a technique with which they are less comfortable. Therefore, the purpose of this study was to compare the linear and temporal stride patterns of healthy horses versus those of horses with chronic laminitis and to measure the effects of three different types of clog shoes on horses with stable chronic laminitis using kinematic analysis.

The Universidade Federal de Minas Gerais Ethics Committee on Animal Use approved this study (Approval No. 56/2014). Twelve Mangalarga
Marchador mares were included, six healthy and six with laminitis. The healthy mares were considered clinically normal through physical, lameness, and hematological exams. The mean \pm standard deviation (range) ages were $8.3 \pm 4.7$ (3-15) and $10.2 \pm 3.85$ (5-16) years, the mean body condition scores were $7 \pm 0.5$ (7-8) and $5 \pm 1$ (4-6), and the mean body weights were $381 \pm 26(330-410)$ and $381 \pm 11$ (360-390) kg, respectively.

The horses that were included in this study were owned by the Universidade Federal de Minas Gerais and were transferred from the farm to the Veterinary Teaching Hospital (EV-UFMG). The inclusion criterion for the healthy horses was that they had no observable abnormalities in their musculoskeletal systems. The laminitic horses that were included were being treated at the veterinary teaching hospital during the period between 2015-2018. All the horses had stable chronic laminitis that presented with signs that were similar to those of Obel grade 2 acute laminitis and with a dorsal phalangeal rotation between 8-16 degrees in both forelimbs, confirmed via radiographs in the lateromedial position of the hoof. During the experimental period, the horses stayed in individual stalls, and water and hay ad libitum and commercial feed were provided twice a day in the amount of $1 \%$ of their body weight.

The healthy horses were not administered any treatment and were only compared with the laminitic unshod horses. The laminitic horses were subject to four treatments: no clog shoes (NCS), wooden clog shoes (WCS), leather \& EVA (Ethylene-vinyl acetate) clog shoes (LECS), and wooden \& EVA clog shoes (WECS). The clog shoes had the same thickness $(30 \mathrm{~mm})$ and shape and covered the entire distal surface of the hoof on the top, but the ground surface was reduced by $1.5 \mathrm{~cm}$ on the dorsal, lateral, and medial edges in order to avoid the load on the hoof wall, reducing breakover distance (Figure 1A). Six screws $(4 \times 35 \mathrm{~mm})$ were used (three medially and three laterally) to attach the clog shoes to the hoof wall. 
In order to avoid a possible hind limb pain interference with the forelimb kinematics, a nerve block with bupivacaine was performed in the sesamoid abaxial region bilaterally in the hind limbs.

Each horse was treated with all the types of orthoses in a randomized sequence with 60-minute intervals between the treatments and were evaluated 10 minutes after shoe placement. The orthoses were always placed by the same researcher after trimming the hoof to reestablish the distal phalanx alignment with the hoof capsule according to the standard technique (O'GRADY, 2013).

Figure 1. 1A) View of the orthoses used in the chronic laminitis group, from left to right: leather \& EVA (Ethylenevinyl acetate) clog shoe (LECS), wooden clog shoe (WCS), and wooden \& EVA clog shoe (WECS). 1B-D) Cinematic analysis of the right forelimb of a healthy Mangalarga Marchador mare at a walk showing the time of the first impact, starting stance phase (B); the final moment of the stance phase, starting swing phase (C); and the time of the second impact, finishing the swing phase (D).
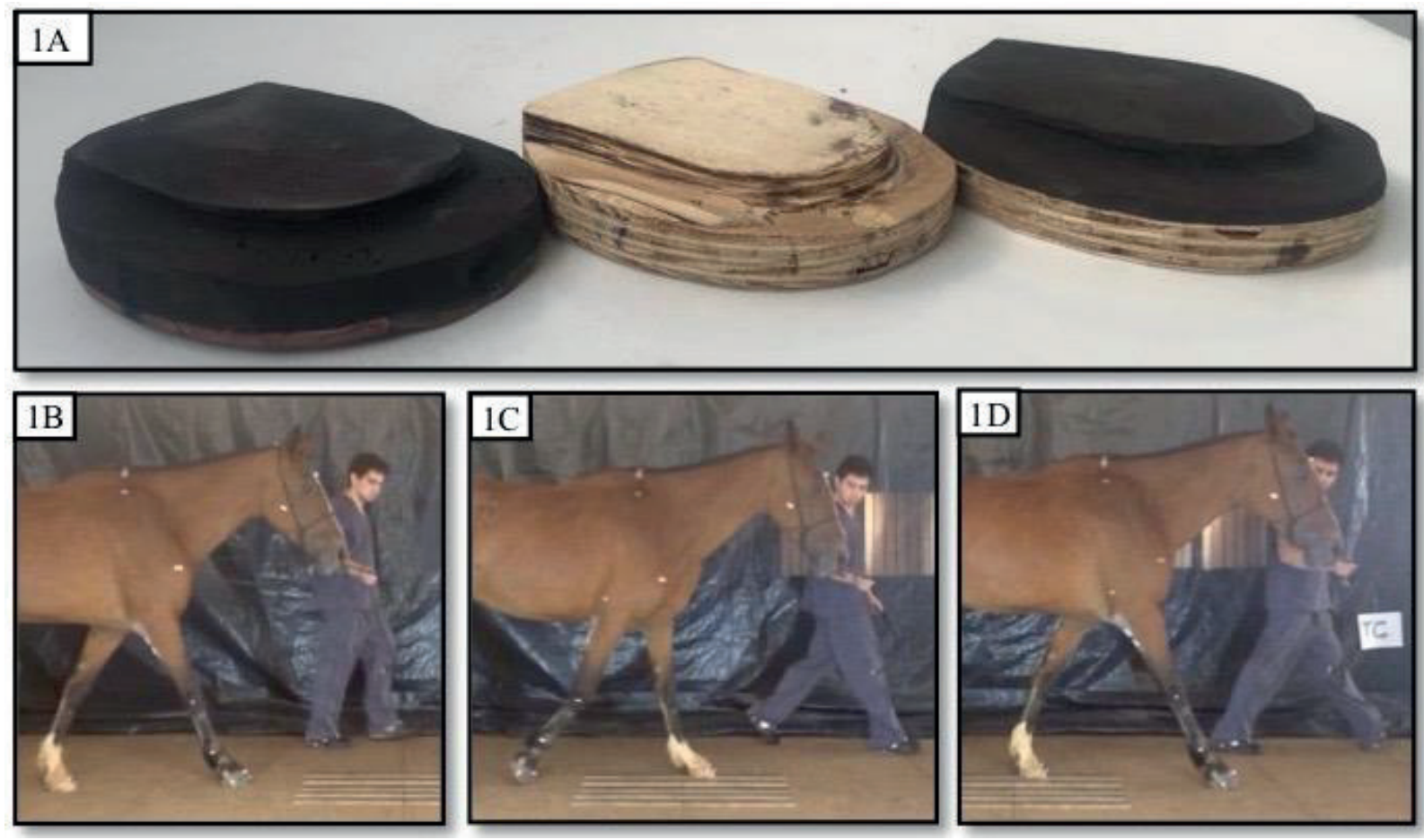

For the kinematic evaluation, reflective markers, measuring $2.5 \mathrm{~cm}$ in diameter, were glued by the same researcher to the hooves on the left and right sides of all the horses. Three markers were fixed to the lateral hoof wall forming a triangle: one close to the heels and the other two parallel to the foot axis (adapted from CLAYTON et al., 2013). Filming was performed on a flat concrete surface, 20 meters in length, thus providing an adequate area for the acceleration/deceleration of the animals.
All the horses were guided to walk along a straight line by the same person. A Canon SX-50 camera (Melville - NY, USA) was used at a frequency of $120 \mathrm{~Hz}$ and was positioned perpendicular to and at a distance of 4 meters from the central point of the runway, where six parallel lines (one-meter length) were painted on the ground as a reference for the calibration. To minimize the effect that speed has on the changes in the temporal measurements, the handler was instructed to maintain a constant speed 
for each horse, always at a walking pace, and to ignore the head movements of the horse during the filming. Five trial videos were obtained on each side of the animals. One video of each horse from each side was selected for the assessment of the effect of the treatments on stride characteristics. The selected videos were those in which the horses performed a complete stride with visualization of the reflective markers.

The images were analyzed using the software, Tracker Video Analysis and Modeling Tool (software free). A stride was defined as the interval between the two moments of impact of the heels to the ground. For each forelimb, the stance phase was defined as the period from the first impact (heel-first, flat foot, or toe-first) until the toe left the ground; the breakover was defined as the time period between when the heel left the ground and the toe left the ground, comprising the terminal part of the stance phase (Figure 1B, 1C, and 1D). To compare the healthy horses to those with laminitis and to compare the effect of the treatments on the gait of the forelimbs in horses with chronic laminitis, the following variables were analyzed: stride duration, stance phase duration, relative stance duration as a percentage of the stride duration, breakover duration, swing duration, stride length, and velocity.
The speed $(\mathrm{m} / \mathrm{s})$ was calculated by multiplying the stride length and stride frequency, and the stride frequency was calculated by dividing 1 by the stride duration.

For the statistical analyses, the mean value obtained from both sides was considered for each variable. Normal distribution was confirmed by the Shapiro-Wilk test. In order to identify significant differences between healthy horses and laminitic ones, an unpaired Student $t$ test was performed. Concerning the different treatment types administered to the laminitic horses, a paired Student $t$ test was performed in order to compare the unshod group with each of the other groups. The level of statistical significance used was $P<0.05$ (GraphPad Prism 7.0).

None of the laminitic horses displayed an increase in the Obel score during and after the evaluations. The statistics for stride duration, stance phase duration, relative stance duration, breakover duration, swing duration, speed, stride length, and stride frequency are presented in Table 1. When comparing between normal and laminitic horses without shoes, differences $(\mathrm{P}<0.05)$ were found in the case of relative stance duration, swing duration, and stride length.

Table 1. Mean $( \pm$ SD) values for stride kinematic variables of healthy horses $(n=6)$ and laminitic $(n=6)$ horses either treated with three different types of orthopedic shoes or not.

\begin{tabular}{lcccccc}
\hline \multicolumn{1}{c}{ Variable } & & HH & NCS & WCS & LECS & WECS \\
\hline \multirow{2}{*}{ Stride duration (s) } & RF & $1.29 \pm 0.12$ & $1.22 \pm 0.11$ & $1.18 \pm \mathbf{0 . 0 6}$ & $1.18 \pm \mathbf{0 . 0 5}$ & $1.22 \pm \mathbf{0 . 0 7}$ \\
& LF & $1.31 \pm 0.15$ & $1.18 \pm 0.10$ & $1.16 \pm 0.09$ & $1.19 \pm 0.05$ & $1.21 \pm 0.07$ \\
& Forelimb & $1.30 \pm \mathbf{0 . 1 3}$ & $1.20 \pm \mathbf{0 . 1 0 ^ { \mathrm { a } }}$ & $1.17 \pm 0.06^{\mathrm{a}}$ & $1.19 \pm 0.04^{\mathrm{a}}$ & $1.22 \pm 0.05^{\mathrm{a}}$ \\
\hline \multirow{2}{*}{ Stance phase } & RF & $0.83 \pm 0.10$ & $0.84 \pm 0.09$ & $0.80 \pm 0.08$ & $0.79 \pm 0.05$ & $0.82 \pm 0.07$ \\
duration (s) & LF & $0.84 \pm 0.13$ & $0.80 \pm 0.05$ & $0.78 \pm 0.08$ & $0.80 \pm 0.06$ & $0.81 \pm 0.09$ \\
& Forelimb & $0.84 \pm 0.11$ & $0.82 \pm 0.06^{\mathrm{a}}$ & $0.79 \pm 0.07^{\mathrm{a}}$ & $0.79 \pm 0.05^{\mathrm{a}}$ & $0.82 \pm 0.06^{\mathrm{a}}$ \\
\hline \multirow{2}{*}{ Relative stance } & RF & $64.4 \pm 2.1$ & $68.4 \pm 2.2$ & $67.8 \pm 3.4$ & $66.7 \pm 1.6$ & $67.4 \pm 3.1$ \\
duration (\%) & LF & $64.0 \pm 2.6$ & $67.8 \pm 3.4$ & $67.0 \pm 4.3$ & $67.1 \pm 2.5$ & $66.9 \pm 3.4$ \\
& Forelimb & $64.2 \pm 2.2^{*}$ & $68.1 \pm 2.5^{\mathrm{a}}$ & $67.4 \pm 3.8^{\mathrm{a}}$ & $66.9 \pm 1.9^{\mathrm{a}}$ & $67.1 \pm 2.9^{\mathrm{a}}$ \\
\hline \multirow{2}{*}{ Breakover } & RF & $0.07 \pm 0.01$ & $0.07 \pm 0.01$ & $0.07 \pm 0.02$ & $0.05 \pm 0.01$ & $0.07 \pm 0.03$ \\
duration (s) & LF & $0.08 \pm 0.02$ & $0.07 \pm 0.02$ & $0.08 \pm 0.01$ & $0.07 \pm 0.02$ & $0.06 \pm 0.03$ \\
& Forelimb & $0.08 \pm 0.01$ & $0.07 \pm 0.01^{\mathrm{a}}$ & $0.07 \pm 0.01^{\mathrm{a}}$ & $0.06 \pm 0.01^{\mathrm{a}}$ & $0.06 \pm 0.02^{\mathrm{a}}$ \\
\hline
\end{tabular}

continue 
continuation

\begin{tabular}{lcccccc}
\hline \multirow{3}{*}{ Swing duration (s) } & RF & $0.46 \pm 0.02$ & $0.39 \pm 0.04$ & $0.38 \pm 0.03$ & $0.39 \pm 0.01$ & $0.40 \pm 0.03$ \\
& LF & $0.47 \pm 0.03$ & $0.38 \pm 0.06$ & $0.38 \pm 0.05$ & $0.39 \pm 0.02$ & $0.40 \pm 0.02$ \\
& Forelimb & $0.46 \pm 0.02^{*}$ & $0.38 \pm 0.05^{\mathrm{a}}$ & $0.38 \pm 0.04^{\mathrm{a}}$ & $0.39 \pm 0.01^{\mathrm{a}}$ & $0.40 \pm 0.03^{\mathrm{a}}$ \\
\hline \multirow{3}{*}{ Speed (m/sec) } & RF & $1.29 \pm 0.14$ & $1.23 \pm 0.13$ & $1.32 \pm 0.18$ & $1.36 \pm 0.16$ & $1.31 \pm 0.17$ \\
& LF & $1.31 \pm 0.21$ & $1.26 \pm 0.15$ & $1.36 \pm 0.24$ & $1.35 \pm 0.19$ & $1.31 \pm 0.15$ \\
& Forelimb & $1.30 \pm 0.18$ & $1.25 \pm 0.12^{\mathrm{a}}$ & $1.34 \pm 0.20^{\mathrm{a}}$ & $1.35 \pm 0.16^{\mathrm{a}}$ & $1.31 \pm 0.15^{\mathrm{a}}$ \\
\hline \multirow{3}{*}{ Stride length (cm) } & RF & $165 \pm 11,5$ & $149 \pm 12.0$ & $160 \pm 13.9$ & $159 \pm 14.9$ & $158 \pm 14.0$ \\
& LF & $168 \pm 14.8$ & $148 \pm 16.1$ & $154 \pm 09.8$ & $1.60 \pm 16.2$ & $157 \pm 13.3$ \\
& Forelimb & $167 \pm 12.9^{*}$ & $149 \pm 11.7^{\mathrm{a}}$ & $157 \pm 10.8^{\mathrm{b}}$ & $159 \pm 14.8^{\mathrm{a}}$ & $158 \pm 13.4^{\mathrm{a}}$ \\
\hline \multirow{2}{*}{ Frequency } & RF & $0.78 \pm 0.07$ & $0.82 \pm 0.07$ & $0.85 \pm 0.04$ & $0.85 \pm 0.04$ & $0.82 \pm 0.04$ \\
(stride/sec) & LF & $0.77 \pm 0.09$ & $0.85 \pm 0.07$ & $0.87 \pm 0.04$ & $0.83 \pm 0.05$ & $0.83 \pm 0.05$ \\
& Forelimb & $0.78 \pm 0.08$ & $0.84 \pm 0.06^{\mathrm{a}}$ & $0.86 \pm 0.05^{\mathrm{a}}$ & $0.84 \pm 0.03^{\mathrm{a}}$ & $0.83 \pm 0.03^{\mathrm{a}}$ \\
\hline
\end{tabular}

$\mathrm{HH}=$ Healthy horses. Laminitic horses with $\mathrm{NCS}=$ no clog shoes, WCS = wooden clog shoes, LECS= leather \& EVA clog shoes, $\mathrm{WECS}=$ wooden \& EVA clog shoes. $\mathrm{RF}=$ right forelimb; $\mathrm{LF}=$ left forelimb. $*$ Different from HH via Student's unpaired t-test at $\mathrm{P} \leq 0.05$. Different letters on the same line indicate a significant difference between laminitic horses evaluated by Student $s$ paired t-test at $\mathrm{P} \leq 0.05$.

The kinematic variable values of the healthy group (Table 1) were similar to those generated in previous studies conducted on healthy horses belonging to other breeds that employed different kinematic methodologies (BACK et al., 1996; HODSON et al., 2000; MOORMAN et al., 2013; MORALES-ACOSTA et al., 2018). In the present study, it was possible to verify the differences in linear and temporal kinematics between healthy horses and laminitic horses. The results demonstrated that horses with laminitis have a stride length reduced by $11 \%(\mathrm{P}=0.03)$, and a swing phase, by $18 \%(\mathrm{P}$ $=0.004)$, and they have a relative stance phase of each limb that is prolonged by $6 \%(\mathrm{P}=0.02)$ when compared with the healthy group. Such changes can be explained as the consequences of the weakened connection between the hoof capsule and the distal phalanx that occurs in horses with laminitis. The reposition of the distal phalanx compresses the corium of the hoof capsule, mainly in the sole and in the proximal region of the dorsal wall promoting ischemia, which may lead to bone exposure through the sole and necrosis in the dorsal region (O'GRADY; PARKS, 2008). Further, lameness and changes in the biomechanics of locomotion may be consequences of pain resulting from this process.
These results, even if the horse is affected by bilateral lameness, corroborate previous findings elucidating that the duration of the stance phase in the forelimb is prolonged in horses based on the degree of lameness, according to the scientific results compiled by Buchner (2013). This effect is proposed to be an important mechanism responsible for the reduction and redistribution of the peak force that occurs during the stance phase, and it also allows the horse to reduce the duration of the swing phase, resulting in a lower degree of propulsion of the affected limb (BUCHNER, 2013). Our results are also in accordance with those of a study that compared the kinematics and ground reaction forces of the forelimbs between healthy and laminitic ponies when the ponies moved at a lower speed and displayed an increased duration of the stance phase (MCGUIGAN et al., 2005). These authors also showed a concomitant reduction in the tension force in the deep digital flexor tendon in the beginning of the mid-stance phase, which may occur in the case of the horses included in the present study.

No differences were found while comparing the outcomes of the treatments administered to the horses with laminitis, except in the case of the stride length, which was longer in the horses with WCS 
clogs when compared with in unshod laminitic horses. The effect of wooden shoes on increasing stride length may be related to a reduction of the extensor moment of the center of rotation of the distal interphalangeal joint and the consequent reduction of the forces exerted by the deep digital flexor tendon during the breakover phase. Due the presence of EVA, a flexible material, the other orthoses did show the same results. Authors such as Steward (2003) and O'Grady (2013) have reported that the use of clog shoes to treat horses with laminitis promotes marked clinical improvement. O'Grady (2013) describes the various advantages of using this type of orthosis that include the simplicity of construction and application, the resulting empirical improvements in the movement during the breakover phase, less tension in the digital deep flexor tendon, and the preservation of the integrity of the wall and the sole of the hoof.

In a recent study, the kinetic effects of a frogsupportive mouldable shoe similar to the ones used in the present study were evaluated in obese ponies, which were predisposed to endocrinopathic laminitis (SLEUTJENS et al., 2018). The benefits of the shoes in terms of the vertical impulse and peak vertical force in obese and non-obese ponies were not observed immediately, but only after 72 hours following the application. Differences were detected in the stance phase duration, toe-heel index, and toe-heel balance curves between the obese and nonobese ponies, all of which became more comparable between the groups after the application of the frogsupportive shoes (SLEUTJENS et al., 2018). In light of the absence of benefits immediately after the frogsupportive shoes were applied to the ponies, it was considered that a lengthier time period is necessary in order to evaluate the real kinematic effects of the orthesis placement in the present study. Further studies with horses that are in different phases of laminitis (like acute and chronic unstable) and that allow for a longer period of time for the horses to adapt to the orthoses will be important in order not to overlook the limitations of the present work.
In conclusion, the forelimbs of laminitic and unaffected horses display differences in stride kinematics at a walk, with a reduced stride length and swing phase duration and a prolonged relative stance phase duration in laminitic horses. Remarkable and immediate benefits were not observed with all the types of orthoses that were implemented to treat the stable chronic laminitic horses; however, stride length improvements were detected with the use of the wooden shoe. Further studies are still needed to assess the prolonged effects that clog shoes have in the different phases of equine laminitis.

\section{Acknowledgements}

Ao CNPq (Produtividade de Pesquisa e bolsa de doutorado), CAPES (Bolsa doutorado-sanduíche) e FAPEMIG (Pesquisador Mineiro) pelo apoio financeiro.

\section{References}

BACK, W.; SCHAMHARDT, H.; BARNEVELD, A. Are kinematics of the walk related to the locomotion of a Warmblood horse at the trot? The Veterinary Quarterly, London, v. 18, p. 79-84, 1996. Supplement 2. DOI: 10.1080/01652176.1996.9694699

BELKNAP, J. Laminitis: an overview. In: BELKNAP, J.; GEOR, R. Equine laminitis. Oxford: John Wiley \& Sons, Inc, 2017. p. 11-12.

BUCHNER, H. Gait adaptation in lameness. In: BACK, W.; CLAYTON, H. Equine locomotion. St. Louis: Saunder Elsevier, 2013. p. 175-197.

CLAYTON, H.; CHATEAU, H.; BACK, W. Forelimb function. In: BACK, W.; CLAYTON, H. Equine locomotion. St. Louis: Saunder Elsevier, 2013. p. 99-125.

ELIASHAR, E. An evidence-based assessment of the biomechanical effects of the common shoeing and farriery techniques. Veterinary Clinics of North America: Equine Practice, St. Louis, v. 23, n. 2, p. 425-442, 2007. DOI: $10.1016 /$ j.cveq.2007.03.010

ELIASHAR, E. The biomechanics of the equine foot as it pertains to farriery. Veterinary Clinics of North America: Equine practice, St. Louis, v. 28, n. 2, p. 283-291, 2012. DOI: $10.1016 /$ j.cveq.2012.06.001 
HODSON, E.; CLAYTON, H. M.; LANOVAZ, J. L. The forelimb in walking horses: 1. kinematics and ground reaction forces. Equine Veterinary Journal, London, v. 32, n. 4, p. 287-294, 2000. DOI: $10.2746 / 042516400777032237$

MCGUIGAN, P.; WALSH, T.; PARDOE, C.; DAY, P.; WILSON, A. Deep digital flexor tendon force and digital mechanics in normal ponies with rotation of the distal phalanx as a sequel to laminitis. Equine Veterinary Journal, London, v. 37, n. 2, p. 161-165, 2005. DOI: $10.2746 / 0425164054223859$

MOORMAN, V. J.; REISER II, R. F.; PETERSON, M. L.; McILWRAITH, C. W.; KAMCAK, C. E. Effect of forelimb lameness on hoof kinematics of horses at a walk. American Journal of Veterinary Research, Schaumburg, v. 74, n. 9, p. 1192-1197, 2013. DOI: 10.2460/ajvr.74.9.1192

MORALES-ACOSTA, L.; ORTIZ-PRADO, A.; JACOBARMENDÁRIZ, V.; GONZÁLEZ-CARBONELL, R. Analysis and characterization of the normal gait phases of walking Warmblood horses as a tool for the diagnosis of lameness. Pesquisa Veterinária Brasileira, Seropédica, v. 38 , n. 3 , p. $536-543$, 2018. DOI: 10.1590/1678-5150pvb-4496

O'GRADY, S. Many uses and application of the wooden shoe. American Association of Equine Practitioners
Focus on the Foot Proceedings, Lexington, v. 1, n. 1, p. 50-54, 2013.

O'GRADY, S.; PARKS, A. Farriery options for acute and chronic laminitis. Proceedings of the 54th Annual Convention of the American Association of Equine Practitioners, Lexington, v. 54, p. 354-363, 2008.

O'GRADY, S.; STEWARD, M. The wooden shoe as an option for treating chronic laminitis. Equine Veterinary Education, London, v. 21, n. 2, p. 107-112, 2009. DOI: $10.2746 / 095777309 \times 397888$

PARKS, A. Hoof care management of horses with displacement of the distal phalanx. In: BELKNAP, J.; GEOR, R. Equine laminitis. Oxford: John Wiley \& Sons, Inc, 2017. p. 364-374.

SLEUTJENS, J.; SERRA BRAGANÇA, F.; VAN EMPELEN, M.; TEM HAVE, R.; ZWAAN, J.; ROELFSEMA, E.; OOSTERLINCK, M.; BACK, W. Mouldable, thermoplastic, glue-on frog-supportive shoes change hoof kinetics in normal and obese Shetland ponies. Equine Veterinary Journal, London, v. 50, n. 5, p. 1-6, 2018. DOI: $10.1111 /$ evj.12814

STEWARD, M. How to construct and apply atraumatic therapeutic shoes to treat acute or chronic laminitis in the horse. Proceedings of the 49th Annual Convention of the American Association of Equine Practitioners, Lexington, v. 49, p. 337-346, 2003. 